\title{
Taxonomic study of Polystachya Hook. (Orchidaceae) from Asia
}

\author{
Joanna Mytnik-Ejsmont • Przemysław Baranow
}

Received: 16 April 2010/Accepted: 13 August 2010/Published online: 14 September 2010

(C) The Author(s) 2010. This article is published with open access at Springerlink.com

\begin{abstract}
In Asia, three species of Polystachya (Orchidaceae) are recognized, based on detailed morphological studies. They occur in southern Asia, from Tamil Nadu State in southern India and Yunnan Province in southeastern China to Sumbawa Island in southern Indonesia. As circumscribed here, two Asiatic species are endemic to southern India apart from $P$. concreta, which is a taxon of pantropical distribution. As part of a detailed nomenclatural review, 21 lectotypes and 1 neotype are designated. For each species treated, a full synonymy, detailed description, illustration, and distribution map are provided. A key for determination of the Asiatic species is included. One species from southeastern India (Kalrayan Hills) is newly described: $P$. seidenfadeniana. Dendrobium parvum Seidenf. is reduced to a synonym of Polystachya concreta (Jacq.) Garay \& H.R. Sweet.
\end{abstract}

Keywords Taxonomy $\cdot$ Lectotype $\cdot$ Neotype $\cdot$ New species $\cdot$ Polystachya concreta $\cdot$ Asia

\section{Introduction}

Polystachya Hook. (Orchidaceae) is a large, predominantly epiphytic genus comprising about 230 species. It is characterized by a more or less pseudobulbous stem, an inflorescence arising from the top of the pseudobulb, nonresupinate flowers with often prominent mentum (a chin-like structure formed by adnation of the lateral sepals and long column foot), short and massive column, and

J. Mytnik-Ejsmont $(\bowtie) \cdot P$. Baranow

Department of Plant Taxonomy and Nature Conservation, Gdansk University, Al. Legionow 9, 80-441 Gdansk, Poland e-mail: dokjom@univ.gda.pl superposed pollinia. The genus is of pantropical distribution, though the vast majority of polystachyas grow in the tropical part of Africa. Nineteen species occur in Madagascar and the Indian Ocean Islands, 13 are found in the Neotropics, and 3 in tropical Asia.

All three Asiatic Polystachya species represent the typical section of the genus. They are epiphytic plants with basally thickened stems covered by the leaf bases, oblanceolate to obovate and deciduous leaves, racemose or paniculate and many-flowered inflorescence, small to medium, fleshy, glabrous or pubescent flowers, and threelobed lip often furnished with a central ridge-like callus covered densely with pseudopollen.

Asiatic polystachyas were classified variously according to different authors. Hooker (1894) presented three species from India, P. purpurea Wight, P. zeylanica Lindl., and $P$. wightii Rchb.f. with a comment that more specimens of the latter species need to be analyzed. Two years later, Ridley (1896) described three new species of Polystachya from the Malay Peninsula, $P$. penangensis, P. singapurensis, and $P$. siamensis. The latter species was accepted by Smith (1933), who listed it together with P. flavescens (Blume) J.J. Smith. However, Holttum (1957) recognized all three of Ridley's species ( $P$. penangensis, $P$. singapurensis, and $P$. siamensis) as synonyms of $P$. flavescens. Dassanayake and Fosberg (1981) gave information about the sole species of Polystachya occurring in Sri Lanka, P. concreta (Jacq.) Garay \& H.R. Sweet, and commented that the species is closely related to $P$. wightii Rchb.f. from southern India, though the two species differ in size, with the latter being a smaller plant. In the opinion of Valmayor (1984), P. luteola is the only representative of the genus in the Philippines. The author presented an extensive synonymy list. Isaac-Williams (1988) recognized P. flavescens as the only Asiatic species of Polystachya; P. siamensis 
was found as a synonym of $P$. flavescens. The authors of the recent Floras of particular parts of Asia (India, Borneo, China, Thailand, Laos, Vietnam, Philippines) claim that $P$. concreta is the only Asiatic species of the genus Polystachya (Wood et al. 1993; Sathish Kumar and Manilal 1994; Wood and Cribb 1994; Bose et al. 1999; Singchi et al. 1999; Schuiteman and de Vogel 2000; Cootes 2001).

The confusion regarding the identity of $P$. concreta is often caused by infraspecific variability. The development and length of the inflorescence is not a very good character to distinguish species within the $P$. concreta complex (especially when treated as the only key character), as there are some intermediate forms between the simple and branched raceme, and this character should be used carefully. The shape and proportions of the lip are also problematic characters; however, when used cautiously and with consciousness of infraspecific variability, they can be good distinguishable features (Fig. 1).

The lip of $P$. concreta is distinctly three-lobed, unguiculate, though sometimes the claw is obscure. The
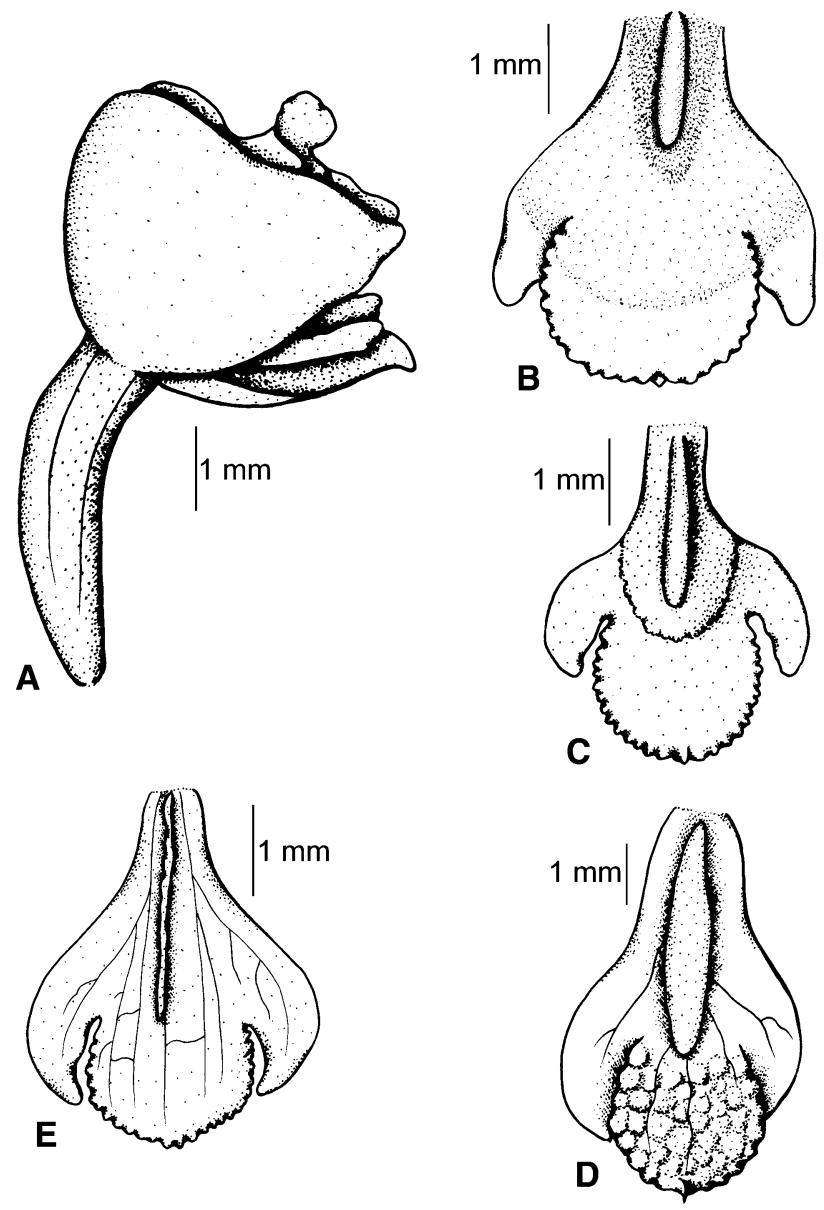

Fig. 1 Polystachya concreta (Jacq.) Garay \& H.R. Sweet: a flower, b-e lip variability [drawn by Baranow from: a, b G.T. 5023 (C-spirit), c N. Jacobsen 18-16 (C-spirit), d J. Garcia 703 (B), e A.R. Torre 5280 (C)] lateral lobes are prominent, oblong, oblong-ovate to triangular, obtuse to subacute, reaching at least half length of the middle lobe, often longer. The middle lobe is widely oblong to almost orbicular or widely ovate, obtuse or rounded with small fleshy apiculus. The ridge-like fleshy callus is prominent set along the mid-nerve from the base of the lip up to the base of the middle lobe, covered with the moniliform, pseudopollen-forming uniseriate trichomes (Davies et al. 2002). The variability of the lip form is seen especially in the length and width of the lateral lobes, shape and size of the middle lobe, and proportions between the three lobes (Fig. 1).

\section{Materials and methods}

A standard procedure of using the herbarium material was applied. The vegetative and floral characters of individual plants were analyzed. Particular parts of the flower were boiled, dissected, measured, and drawn under a binocular microscope. The results were then compared with the type material, diagnoses, and original illustrations. Each studied specimen was photographed. The database of the studied material is available in the first author's archives. The material for the study was loaned from or examined in 13 herbaria (B, BKF, BM, BR, C, K, L, MA, MO, P, U, WAG, W). Apart from 66 specimens collected from Asia, 315 herbarium specimens and spirit material as well from the whole range of distribution of $P$. concreta were analyzed in detail to establish the scope of variability of the species. Thirty-one type specimens of 30 heterotypic synonyms of $P$. concreta were carefully studied.

\section{Results and discussion}

After detailed studies of 66 specimens of $P$. concreta complex collected from Asia and more than 300 from the Neotropics, Africa, and Madagascar, we conclude that the vast majority of them are represented by the variable and widely distributed species $P$. concreta. Besides, we recognize two species endemic to the South India Region: $P$. wightii being found in the Tamil Nadu and Kerala States, and the newly proposed species, P. seidenfadeniana, occurring in the Periakalrayans (Tamil Nadu State) only. Tamil Nadu ranks first among all the states of India with 533 endemic plant species, which constitutes almost $10 \%$ of all plant species occurring in the region (ENVIS 2006).

Thus we recognize three species of Polystachya in Asia, which are presented below.

A key for determination of Asiatic species of Polystachya: 
1. Lip distinctly three-lobed, lateral lobes prominent, middle lobe as wide as or wider than long: 2

1. Lip obscurely three-lobed, lateral lobes obscure, middle lobe markedly longer than wide: $P$. seidenfadeniana

2. Lip sessile, lacking a callus, lateral lobes short, middle lobe widely obovate: $P$. wightii

2. Lip clawed, furnished with prominent, linear, fleshy, ridge-like callus, lateral lobes prominent, middle lobe widely oblong to widely ovate: $P$. concreta

Polystachya seidenfadeniana Mytnik \& Baranow $s p$. nov. (Fig. 2)

P. concreta arcte similis est sed labellum hastatum obscure trilobatum est, lobi laterales late triangulares obtusique sunt, lobus intermedius valde longior quam latus est.

Type: INDIA. Tamil Nadu: Salem District, Attur Periakalrayans, alt. $950 \mathrm{~m}, 1$ July 1978, Matthew 15260 (Holotype: C, Isotype: RHT - non vidi).

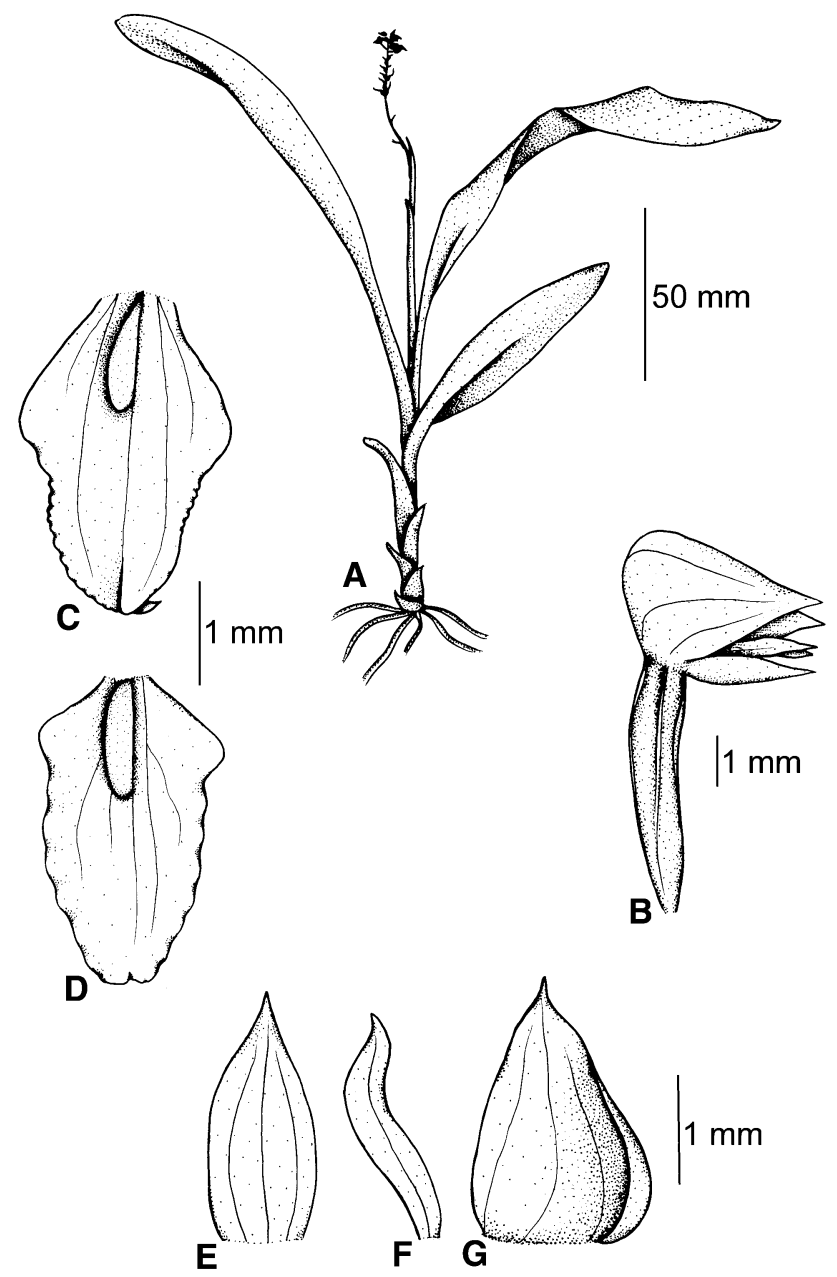

Fig. 2 Polystachya seidenfadeniana Mytnik \& Baranow: a habit, b flower, c-d lip, e dorsal sepal, f petal, g lateral sepal (drawn by Baranow from the holotype)
Small epiphytic plant, up to $17 \mathrm{~cm}$ tall, growing in clusters. Pseudobulbs $2.5 \mathrm{~cm}$ long, $0.5 \mathrm{~cm}$ in diameter, clustered, slender, cylindrical, covered by membranous sheaths at the base and by basal leaves at the upper part. Leaves 3, 7-15 × 1.2-1.5 cm, lanceolate or oblanceolate, cuneate, unequal at the apex. Inflorescence up to $10 \mathrm{~cm}$ long, shorter than the leaves, erect, simple, bearing many flowers. Peduncle covered with tubular, acute sheaths for whole length. Rachis pubescent. Flowers nonresupinate, small, reddish, densely arranged on the peak of the rhachis. Floral bracts up to $3 \mathrm{~mm}$ long, narrowly triangular, glabrous. Pedicel and ovary 4-5.5 mm long, glabrous. Dorsal sepal $3 \times 1.5 \mathrm{~mm}$, ovate-triangular, acuminate, glabrous. Lateral sepals $3.1-3.4 \times 2.5 \mathrm{~mm}$, obliquely triangular, acute to narrowly acute, glabrous. Mentum 2-2.5 mm high, rounded. Petals $2.5 \times 0.5 \mathrm{~mm}$, linear-oblong, acute, falcate. The lip, $2.8-3 \times 1.5-2 \mathrm{~mm}$, very obscurely threelobed at the base, obovate in outline; the lateral lobes very obscure, rounded to broadly triangular and obtuse; the middle lobe $1.6-1.8 \times 1.2-1.3 \mathrm{~mm}$, ovate, side margins crenulate, apex emarginate with apiculus on the back side; the callus $1.2 \times 0.6-0.7 \mathrm{~mm}$, a high, fleshy keel at the base of the lip. Column foot ca. $1.8 \mathrm{~mm}$ long.

Altitude: $950 \mathrm{~m}$.

Distribution: India, endemic to Periakalrayans Hills (Tamil Nadu State), known from the type collection so far (Fig. 4).

Etymology: The name of the new species is dedicated to the late Dr. Gunnar Seidenfaden (1908-2001), an eminent Danish botanist and expert on Southeast Asian orchids.

Discussion: Undoubtedly Polystachya seidenfadeniana is closely related to $P$. concreta, but the inflorescence of the former species is always simple and shorter than the leaves, up to $10 \mathrm{~cm}$ long. The two species differ in the lip structure. The lip of P. seidenfadeniana is widest at its base, up to $1.5 \mathrm{~mm}$ wide, indistinctly basally three-lobed, and somewhat hastate. The lateral lobes of lip are obscure, broadly triangular, and obtuse. The middle lobe of lip is markedly longer than wide, oblong-obovate, tapering, and emarginate at the apex. On the contrary, the lip of P. concreta is characterized by the prominent oblong, oblong-elliptic or triangular lateral lobes reaching at least half length of middle lobe, the latter lobe is often wider than long or as long as wide, in many cases almost orbicular in outline or transversely elliptic. Being aware of the high variability of the lip form within P. concreta, we decided to describe the new species because of the composition of unique characters mentioned above, which make the new entity easily distinguishable from $P$. concreta.

The new entity was found in the Periakalrayans, a part of the Kalrayan Hills (Salem District) lying to the south of the Tumbal River, where the entire slopes are covered by Reserve Forests. 


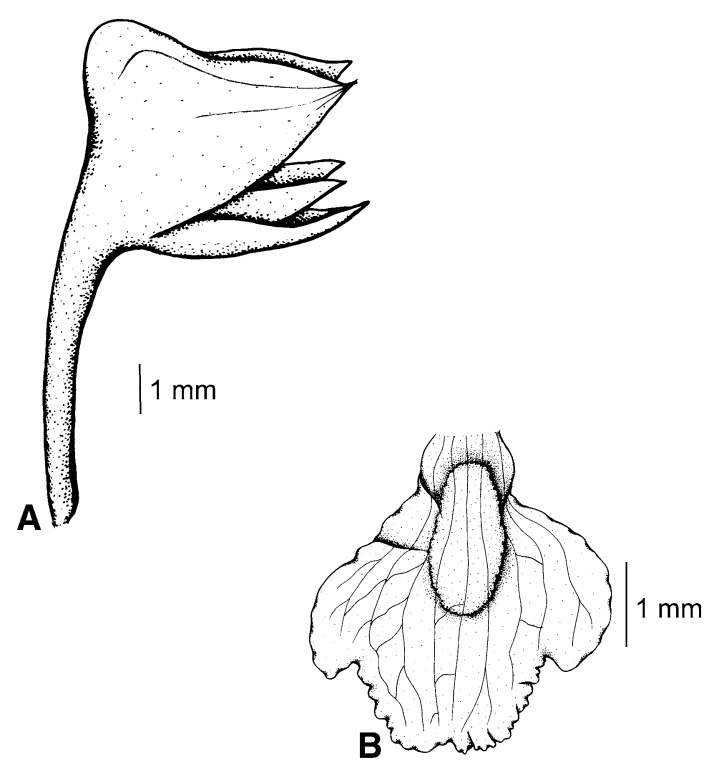

Fig. 3 Polystachya wightii Rchb.f.: a flower, b lip (drawn by Baranow from the holotype)

Polystachya seidenfadeniana is known from one locality so far, but a field survey needs to be carried out to ascertain the distribution range of the species.

Polystachya wightii Rchb.f. (Fig. 3)

Ann. Bot. Syst. 5: 640. 1863; Type (here designated): INDIA. Tamil Nadu: Coimbatore Distr., near Coimbatore, Wight 2990 (Lectotype: K!, Isolectotypes: C!, W!). 三 Dendrorkis wightii Kuntze, Revis. Gen. Pl. 2. 658. 1891.

Epiphytic plants up to $25 \mathrm{~cm}$ tall. Stems elongate, swollen into pseudobulbs at the base, clothed with bases of fallen leafs. Pseudobulbs up to $4 \mathrm{~cm}$ long, ovoid, 2-5leaved. Leaves $12-21 \mathrm{~cm}$ long, $1.5-2.5 \mathrm{~cm}$ wide, papery, oblong-elliptic to elliptic, obtuse or acute. Inflorescence apical, many-flowered, up to $20 \mathrm{~cm}$ long, paniculate, weakly branched, each branch to $3 \mathrm{~cm}$ long, usually much shorter; peduncle elongate, compressed, completely enclosed by scarious sheaths. Flowers yellow or green to greenish-yellow, fleshy, small, glabrous. Floral bracts 2.7-4 mm long, triangular or narrowly triangular, acute, glabrous. Pedicel and ovary up to $6 \mathrm{~mm}$ long, slightly pubescent. Mentum 2-3 mm high. Dorsal sepal 2-3.5 $\times 1.5-2 \mathrm{~mm}$, triangular or widely triangular, acute. Petals $2.2-3 \times 0.5 \mathrm{~mm}$, oblanceolate or spatulate, obtuse or acute. Lateral sepals $2.8-4 \times 1.8-3.3 \mathrm{~mm}$, obliquely triangular, acute. The lip, 2.5-3.7 $\times 3-3.5 \mathrm{~mm}$ wide, wider than long, sessile, three-lobed in the middle, free from callus, covered with glandular hairs in the basal half along the mid-nerve; the middle lobe $1-1.2 \times 2-2.2 \mathrm{~mm}$, widely obovate, with undulate margins, emarginate at apex with a fleshy apiculus on the back side of the lip; the lateral lobes $0.8 \mathrm{~mm}$ wide, reaching up to third length of the middle lobe, oblong-ovate, rounded to obtuse. Column $2.5 \mathrm{~mm}$ long, column foot up to $2.6 \mathrm{~mm}$ long.

Altitude: $900 \mathrm{~m}$.

DisTRIBUTION: Southern India (Fig. 4).

Representative Specimens Examined. INDIA. Tamil Nadu: Coimbatore Distr., near Coimbatore, Wight 2990 (C!, K!, W!). Kerala: Idukki Distr., ca. $20 \mathrm{~km}$ from Idukki on road to Kulamavu, alt. 900 m, C.D.K. Cook, E.M. Rix \& J. Schneller $78(\mathrm{~K} !)$.

Discussion: Some authors consider $P$. wightii as a synonym of $P$. concreta (Garay and Sweet 1974; Bose et al. 1999). However, in our opinion, the two species represent different taxonomic units differing in the lip structure. The lip of the former species is almost sessile, without any callus but furnished with glandular hairs in basal half of the disc, the lateral lobes are small, and the middle lobe is widely obovate, widest at its base. The lip of $P$. concreta is rather distinctly clawed, furnished with a prominent fleshy callus often covered with pseudopollen, the lateral lobes prominent, usually reaching at least half length of the middle lobe, the middle lobe widely oblong to widely ovate.

Polystachya wightii is known from southern India so far, but a field survey needs to be carried out to ascertain the distribution range of the species.

Polystachya concreta (Jacq.) Garay \& H.R. Sweet (Fig. 1)

Orquideologia 9: 206. 1974. E Epidendrum concretum Jacq., Enum. Syst. Pl.: 30. 1760; Type citation: all species described by Jacquin (1760) originated "in Insulis Caribaeis vicinaque Americes continente," but neither specimens nor references to previously published illustrations are given. Type (here designated): MARTINIQUE. 2 August 1936, M. Privault 136 (Neotype: P!).

= Epidendrum minutum Aubl., Hist. Pl. Guiane 2: 824 . 1775. $\equiv$ Dendrorkis minuta (Aubl.) Kuntze, Revis. Gen. Pl. 2: 658. 1891. 三 Polystachya minuta (Aubl.) Britton in Small, Fl. S. E. US. 328. 1903, hom. illeg. [non Polystachya minuta A. Rich. \& Galeotti 1845; nec Polystachya minuta Frapp. \& Cordem. 1895]. 三 Dendrobium polystachyon Sw., Kongl. Vetensk. Acad. Handl. 21: 247. 1800, nom. illeg. incl. spec. prior. [Epidendrum minutum Aubl.]. $\equiv$ Cranichis luteola Sw., Fl. Ind. Occid. 3: 1433. 1804. 三 Polystachya luteola (Sw.) Hook., Exot. Fl. 2: 103. 1824, nom. illeg. incl. spec. prior. [Epidendrum minutum Aubl.]; Type citation: reference to Burmann (1758) including Plumier's illustration of Helleborine ramosa, floribus minimis luteis from the West Indies. Type: Lectotype (Szlachetko et al. 2010) P! (Plumier's icon).

$=$ Dendrobium polystachyum Thouars, Hist. Orchid. t. 85. 1822. [as "polystachys"]; Type: MADAGASCAR. Du Petit-Thouars 21 (Lectotype [Szlachetko et al. 2010]: P!). 
Fig. 4 Distribution map Polystachya in Asia (P. concreta (Jacq.) Garay \& H.R. Sweet black points, P. wightii Rchb.f. black squares, $P$. seidenfadeniana Mytnik \& Baranow black trapezoids)

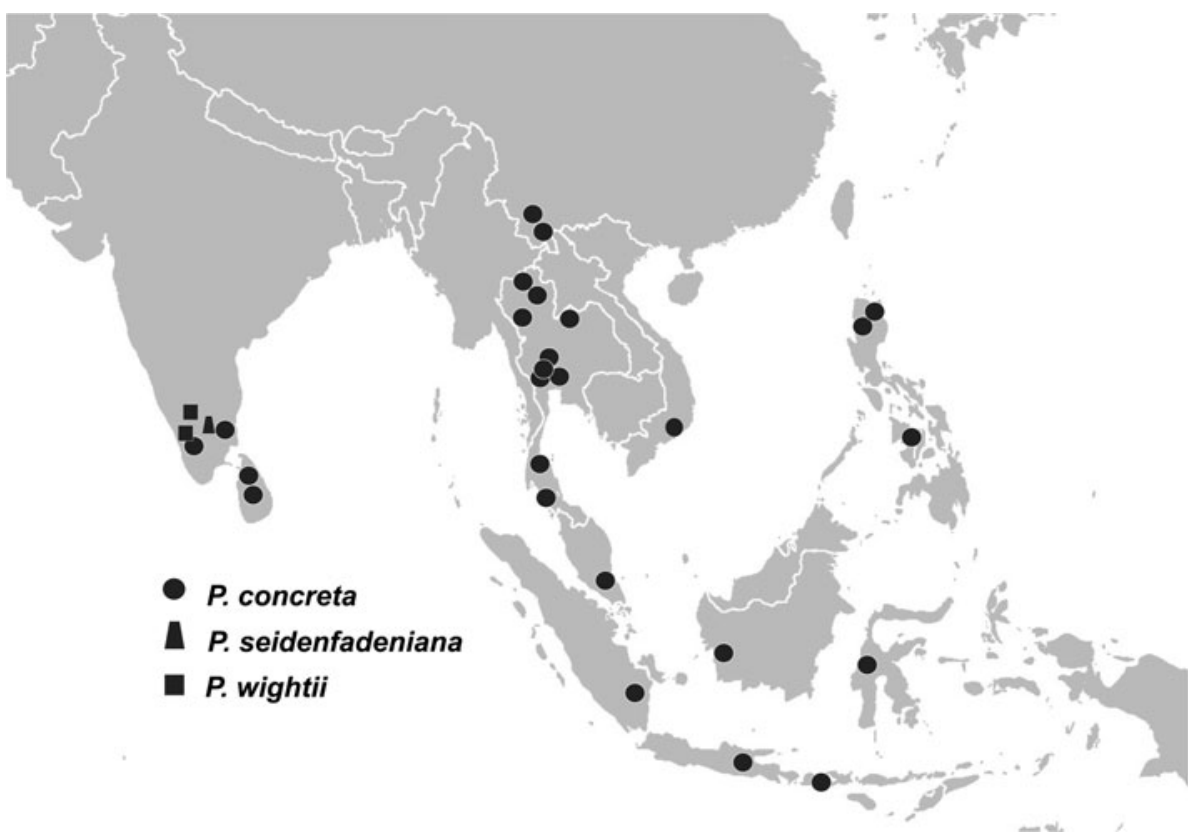

= Onychium flavescens Blume, Bijdr. Fl. Ned. Ind. 7: 325. 1825; Type: JAVA. Salak \& Seribu, Blume s.n. (BO non vidi). $\equiv$ Eria flavescens (Blume) Lindl., Gen. Sp. Orchid. Pl.: 66. 1830. 三 Dendrobium flavescens (Blume) Lindl., Gen. Sp. Orchid. Pl.: 85. 1830. 三 Callista flavescens (Blume) Kuntze, Revis. Gen. Pl. 2: 654. 1891. 三 Polystachya flavescens (Blume) J.J. Sm..

= Polystachya mauritiana Spreng., Syst. Veg. 3: 742. 1826; Type: not designated.

= Polystachya zeylanica Hook., Edwards's Bot. Reg. 24: Misc. 78. 1838; Type: not designated.

= Polystachya purpurea Wight, Icon. Pl. Ind. Orient. 5: 10, pl. 1679. 1852; Type (here designated): INDIA. Tamil Nadu: Madras, Wight 2991 (Lectotype: K! - the plant in the right upper corner of the sheet with one envelope and a drawing). $\equiv$ Maxillaria purpurea (Wight) Beer, Prakt. Stud. Orchid.: 226. 1854. 三 Dendrorkis purpurea (Wight) Kuntze, Revis. Gen. Pl. 2: 658. 1891.

= Polystachya zollingeri Rchb. f., Bonplandia 5: 39 . 1857; Type (here designated): JAVA. Tjikoja, Zollinger 1104 (Lectotype: W!). $\equiv$ Dendrorkis zollingeri (Rchb. f.) Kuntze, Revis. Gen. Pl. 2. 658. 1891.

= Polystachya tessellata Lindl., J. Linn. Soc., Bot. 6: 130. 1862; Type (here designated): NIGERIA. Mann s.n. (Lectotype: K!, Isolectotype: W!). 三 Dendrorkis tessellata (Lindl.) Kuntze, Revis. Gen. Pl. 2. 658. 1891.

= Polystachya extinctoria Rchb.f., Ann. Bot. Syst. (Walpers) 6: 638. 1863; Type: not designated. $\equiv$ Dendrorkis extinctoria (Rchb.f.) Kuntze, Revis. Gen. Pl. 2. 658. 1891.

=Polystachya jussieuana Rchb. f., Ann. Bot. Syst. (Walpers) 6: 641. 1864; Type (here designated):
MADAGASCAR. Jussieu s.n. (Lectotype: W!). $\equiv$ Dendrorkis jussieuana (Rchb. f.) Kuntze, Revis. Gen. Pl. 2: 658. 1891.

= Polystachya tricruris Rchb. f., Flora 50: 118. 1867; Type (here designated): REPUBLIC OF SOUTH AFRICA. KwaZulu-Natal, Sanderson s.n. (Lectotype: $\mathrm{W}$ !). $\equiv$ Polystachya tessellata Lindl. var. tricruris (Rchb. f.) Schelpe, S. African J. Bot. 28: 280. 1963.

= Polystachya rufinula Rchb. f., Gard. Chron. 1: 41 . 1879; Type (here designated): MALAWI. Kirk s.n. (Lectotype: W!, Isolectotype: K!).

= Polystachya hypocrita Rchb. f., Gard. Chron. 2: 685 . 1881; Type (here designated): MALAWI. Christy 799 (Lectotype: W!, K! - drawing).

= Polystachya buchananii Rolfe, Bull. Misc. Inform. Kew 82: 335. 1893; Type (here designated): MALAWI. Buchanan s.n. (Lectotype: K! - the plant on the right side of the sheet, Isolectotype: K!).

= Polystachya penangensis Ridl., J. Linn. Soc., Bot. 32: 344. 1896; Type (here designated): MALAYSIA. Penang: Government Hill, Sine col. (Lectotype: K!).

= Polystachya siamensis Ridl., J. Linn. Soc., Bot. 32: 343 . 1896; Type (here designated): THAILAND. Phang Nga: Pungah, C. Curtis s.n. (Lectotype: K! - Ridley's drawing).

= Polystachya singapurensis Ridl., J. Linn. Soc., Bot. 32: 343. 1896; Type: SINGAPORE. Sungei Morai, Selten s.n (not localized).

= Polystachya pleistantha Kraenzl., Gard. Chron.: 1. 118. 1897; Type: BORNEO. Lauche s.n. (B†).

= Polystachya zanguebarica Rolfe, Fl. Trop. Afr. 7: 115. 1897; Type (here designated): TANZANIA. Zanzibar, Kirk s.n. (Lectotype: K!). 
= Polystachya lehmbachiana Kraenzl., Bot. Jahrb. Syst. 28: 166. 1901; Type (here designated): CAMEROON. Southwest Prov.: Buea, Lehmbach 5 (B†, Lectotype: K! drawing).

=Polystachya gracilis De Wild., Not. Pl. Util. Inter. Fl. Congo 1: 136. 1903; Type (here designated): DEMOCRATIC REPUBLIC OF THE CONGO (ZAIRE). Gentil $45 b$ (Lectotype: BR!, K! - drawing).

= Polystachya latifolia De Wild., Not. Pl. Util. Inter. Fl. Congo 1: 138. 1903; Type (here designated): DEMOCRATIC REPUBLIC OF THE CONGO (ZAIRE). Laurent 1086 (Lectotype: BR!, K! - drawing).

= Polystachya praealta Kraenzl., Bot. Jahrb. Syst. 36: 118. 1905; Type (here designated): LIBERIA. Dinklage 2069 (Lectotype: B!, K! - drawing).

= Polystachya dagremondiana Kraenzl., Vierteljahrsschr. Naturf. Ges. Zurich 60: 428. 1915; Type: SURINAME. D'Angremond s.n (Z - non vidi).

= Polystachya colombiana Schltr., Repert. Spec. Nov. Regni Veg., Beih. 7: 156. 1920; Type: COLOMBIA. Cauca, alt. 500 m, Madero s.n. $(\mathrm{B} \dagger)$.

= Polystachya caquetana Schltr. Repert. Spec. Nov. Regni Veg., Beih. 27: 79. 1924; Type: COLOMBIA. Caqueta, Alt. 530 m., Hopp 160 (B†).

= Polystachya lepidantha Kraenzl., Bull. Misc. Inform. Kew 290. 1926; Type (here designated): UGANDA. Snowden 726 (Lectotype: K!).

= Polystachya lettowiana Kraenzl., Repert. Spec. Nov. Regni Veg. Beih. 39: 54. 1926; Type (here designated): CAMEROON. Baum s.n. (B†, Lectotype: K!).

= Polystachya reichenbachiana Kraenzl., Repert. Spec. Nov. Regni Veg., Beih. 39: 127. 1926; Type (here designated): WEST AFRICA. Reynier 2196 (Lectotype: W!).

= Polystachya purpurea var. lutescens Gagnep. in Lecomte, Fl. Indo-Chine 6: 434. 1934; Type (here designated): VIETNAM. Dalat, Evrard 1118 (Lectotype: P! - a plant on the left side of herbarium sheet, with one leaf). VIETNAM. 16 October 1892, M. A. Regnier s.n. (Paratype: P!). VIETNAM. Annam, Evrard s.n. (Paratype: T - non vidi). VIETNAM, Pierre 6581 (Paratype: P!).

= Dendrobium parvum Seidenf., Opera Bot. 124 :30. 1995, syn. nov. Type: THAILAND. Doi Suthep E side on CMU Conservatory area $850 \mathrm{~m}$, Maxwell 87-1022 (BKF, C).

Plants very variable in size, up to $60 \mathrm{~cm}$ tall. Stems elongate, swollen into pseudobulbs at the base. Pseudobulbs up to $5 \mathrm{~cm}$ long, ovoid, clothed with leaf bases. Leaves 2-6, 3-26 cm long, 0.5-3 cm wide, papery, oblong-elliptic or elliptic to obovate, obtuse or acute, bilobed at the apex. Inflorescence apical, 6-60 cm long, simple or branched at regular intervals, each branch to $8 \mathrm{~cm}$ long, becoming erect, paniculate; peduncle elongate, compressed, completely enclosed by scarious sheaths; branches spicate, loosely many-flowered. Flowers fleshy, rather small, yellow, yellowish-green, dull pink to reddish. Floral bracts $2-3 \mathrm{~mm}$ long, triangular acute, glabrous. Ovary and pedicel 5-8 mm long, glabrous or slightly pubescent. Dorsal sepal 2.5-5 $\times 1.5-3$ (4) mm, oblong-elliptic to triangular-ovate, obtuse. Lateral sepals 3.8-6.5 × 3-4 mm, obliquely triangular, acute. Mentum 2.5-4 mm high, convex to concave. Petals up to $3 \times 0.5-1 \mathrm{~mm}$, oblanceolate, obtuse. Lip $3.5-6 \times 3.3-5 \mathrm{~mm}$, distinctly three-lobed from a cuneate base; the middle lobe $1.8-3 \times 1.5-3 \mathrm{~mm}$, widely oblong or widely ovate to transversely elliptic or almost orbicular, undulate on margins, almost the whole lip covered with a mealy pseudopollen consisting of multicellular, uniserate, moniliform trichomes; the lateral lobes $1-1.8 \times 0.5-1 \mathrm{~mm}$, lanceolate to broadly lanceolate, ovate, elliptic-ovate or ovate to broadly triangular, rounded, obtuse to subacute; the callus 2-3 mm long, linear, fleshy, ridge-like, deriving from the base of the lip reaching the base of the middle lobe. Column ca. $2 \mathrm{~mm}$ high, column foot 2-3.5 mm long.

ECology: A predominantly epiphytic, rarely lithophytic or terrestrial, plant occurring in tropical and subtropical areas, growing in wet montane forest, submontane forest, riverine forest, in the vicinity of savannas, and along creeks. Flowering throughout the year.

Altitude: up to $1,700 \mathrm{~m}$.

Distribution: Pantropical (from southern North America, to tropical South America, tropical and subtropical Africa, Madagascar and the neighboring islands, southeastern Asia).

In Asia: India (Peninsula, Andaman \& Nicobars), Burma, Thailand, Laos, Vietnam, southeastern China, Sri Lanka, Philippines, Sumatra, Malaysia, Bangka, Borneo, Celebes, Java, Bali, Sumbawa (Fig. 4).

Representative Specimens Examined. INDIA. Tamil Nadu: Madurai, Shembaganur-Periakulam bridle path, alt. 1,300 m, 21 Nov 1985, K.M. Matthew, A. Usha \& N. Rajendren 42972 (C!). Nilgiris, Jun 1937, Edward Barnes 1771 (K!). Nilgiris, Ouchterlony Valley, 1944, Edward Barnes 1240 (K!).

CHINA. Yunnan: Mengla Xian, alt. $850 \mathrm{~m}$, Tsi Zhanhuo 91-279 (C!). Yunnan, 15 Mar 1905, A. Henry 13590 \& $13611(\mathrm{~K} !)$.

THAILAND. North: Chiang Mai, Doi Phahom Pok, alt. 1,582 m, 26 Aug 2006, S. Damapong 82 (BKF!). Chiang Mai, $4 \mathrm{~km}$ N of Omkoi, GT 5023 (C-spirit!). North-East: Loei, Phu Kradung, Alt. 1,300 m, 12 May 1905, F. Floto 7328 (BKF!, C!). Loei, Phu Kradung, alt. 1,300 m, 24 Nov 1958, T. Smitinand 4951 (BKF!). West: Kanchanaburi, Khao Buing, alt. 750 m, 16 Aug 1971, CP, BS, BN 2991 (C!). Kanchamburi, Sai Yok, 8 Aug 1928, s. coll. s.n. (K!). Central: Kanchamburi, Si Sawat, alt. 750 m, 30 Jan 1962, T. Smitinand 7400 (BKF!). Ban Laem Nang So Nai, 15 Feb 1966, Seidenfaden \& Smitinand 6471 (C-spirit!). Bangkok, 
A.F.G. Kerr 656 (K!). Thung Salaeng Luang, alt. 1,140 m, 29 Jan 1964, GT 5211 (C!). South: Phang Nga: Pungah, $C$. Curtis s.n. (K!). Ranong, Ngao Fall, alt. 50 m, 22 Aug 1977, T. Santisuk 1235 (BKF!). Trang, alt. 100 m, 22 Aug 1955, Phloenchit 874A (BKF!). Satun, Tarutao, GT 6532 (C-spirit!). Surat Thani, Ko Tao, alt. 300 m, 19 Sep 1918, A.F.G. Kerr 643 (K!). Uncertain localities: Ban Kamp Kep, A.F.G. Kerr 453 (K!). Sine loc., alt. 1300 m, 19 Sep 1908, A.F.G. Kerr 643 (C!); Sine loc., A.F.G. Kerr 867 (C!). Sine loc., A.F.G. Kerr 940 (C!, K!). Sine loc., A.F.G. Kerr 185 (C!). Sine loc., 13 Aug 1988, T.B. Comber 1760 (K!).

VIETNAM. Lam Dong: Da Lat, Evrard 1118 (P!); Sine loco, M. Le D'Thorel s.n. (P!); Sine loco, 16 Oct 1892, M. A. Regnier s.n. (P!); Sine loco, Pierre 6581 (P!).

SRI LANKA. Central: Hakgala, 21 Oct 1909, Dingler 88 (B!). North Central: Ritigala, alt. 750 m, L.H. Cramer 3835 (K!). Western: Agalawatta, L.B. Segerback 3003 (K!). Moragala, S. Waas 1273 (K!). Sine loc. 18 Mar 1975, N. Jacobsen 18-16 (C-spirit!). Gangoruwa, 5 Jun 1904, Gross s.n. (B!).

PHILIPPINES. Luzon: Bontoc, 14 Aug 1914, Morice Vanoverbergh 760 (B!, C!, U!, W!). Bontoc, Alt. 1200 m, May-Jun 1913, M. Vanoverbergh 3670 (K!). Bontoc, 14 Aug 1914, M. Vanoverbergh 760 (C!, U!). Luzon: Rizal, Aug 1911, M. Ramos 13550 (K!). Visayas: Bohol Island, 1923, M. Ramos s.n. (K!).

MALAYSIA. Johor: Tioman, Gunung Kajang, 16 Aug 1988, M. Coleman 10 (K!). Pahang: Fraser's Hills, alt. 1,400 m, B. Segerback 2119 (K!); Government Hill, Sine col. (K!).

INDONESIA. West Kalimantan: Ketapang, Gunung Palung National Park, PulauDatuk beach, 2 Mar 1997, T. G. Laman, Ismail A. Rachman, Edi Mirmanto 555 (K!). South Kalimantan: Banjarmasin, Aug 1857, J. Motley 893 (K!). West Sulawesi: Mamasa area, km 35 on road Mamasa to Polowali, alt. 1,000 m, 9 Sep 2003, Vermeulen J.J. 2279 (C!). East JAVA. Tjikoja, Zollinger 1104 (W!). S of Probolinggo, alt. 500 m, 3 Mar 1982, T.B. Comber 1289 (K!). Java, 1 Jul 1920, Oldens s.n. (U!). Java, 23 Mar 1921, Bakhuizen van den Brik s.n. (U!). North Sumatra: Tambangan, alt. 900 m, 17 Jan 1917, R. Schlechter 15894 (BR!, K!). Sumatra: Sine loc. 21 Jan 1917, Schlechter 15926 (BR!). West Nusa Tenggara: Sumbawa, trail from Batudulang to Pusu, Mt. Batulanteh, alt. 600 m, 23 Apr 1961, Kostermans 18408 (K!).

Acknowledgments We would like to express our gratitude to Professor Dariusz Szlachetko, the head of Department of Plant Taxonomy (Gdansk University, Poland) for inspiration and critical review of the manuscript. We express our gratitude to Dr. Guy Chiron, editor-in-chief of Richardiana, for his priceless help in translating the diagnosis of the new species. This article was prepared thanks to a grant from European Commission's Research Infrastructure Action via the SYNTHESYS Project at the Real Jardin Botanico (CSIC; ESTAF 4129), Natural History Museum of Vienna (AT-TAF 1690, ATTAF-3903), National Botanic Garden of Belgium (BE-TAF-750), National Herbarium of The Netherlands (NL-TAF 2834, NL-TAF2265), Natural History Museum of Denmark (DK-TAF 3231, DKTAF-4040), and Botanic Garden and Botanic Museum in BerlinDahlem (DE-TAF 3906). This study was also supported by grants from the Ministry of Science and Higher Education (N N303 343735 and N N303 094734).

Open Access This article is distributed under the terms of the Creative Commons Attribution Noncommercial License which permits any noncommercial use, distribution, and reproduction in any medium, provided the original author(s) and source are credited.

\section{References}

Bose TK, Bhattacharjee SK, Das P, Basak UC (1999) Orchids of India. Naya Prokash, $487 \mathrm{pp}$

Cootes J (2001) The Orchids of the Philippines. Times Editions, Singapore. $231 \mathrm{pp}$

Dassanayake MD, Fosberg FR (eds) (1981) A revised handbook to the flora of Ceylon. vol 2. Amerind Publ. Co. Ltd., New Dehli, India. $511 \mathrm{pp}$

Davies KL, Roberts DL, Turner MP (2002) Pseudopollen and foodhair diversity in Polystachya Hook. (Orchidaceae). Ann Bot 90:477-484

Environmental Information System (ENVIS) (2006) Chennai: Department of Environment, Government of Tamil Nadu \& Ministry of Environment \& Forests. http://tnenvis.nic.in/biodiversity.htm Retrieved 28 March 2010

Garay LA, Sweet HR (1974) Orchidaceae. In: Howard RA (ed) Flora of the Lesser Antilles, Leeward and Windward Islands. Arnold Arboretum, Harvard University, Jamaica Plain, Massachusetts, p 178

Holttum RE (1957) A revised Flora of Malaya 1. Government Printing Office, Singapore, p 759

Hooker JD (1894) Flora of British India VI. L. Reeve \& Co. Ltd., NR. Ashford, Kent, England, 792 pp

Isaac-Williams ML (1988) An introduction to the orchids of Asia. Angus \& Robertson Publishers, Wellington, New Zealand, $261 \mathrm{pp}$

Ridley HM (1896) The Orchideae and Apostasiaceae of the Malay Peninsula. Journal of the Linnean Society (Botany) 32:213-416

Sathish Kumar C, Manilal KS (1994) A catalogue of Indian orchids. Bishen Singh Mahendra Pal Singh. Dehra Dun, India, 162 pp

Schuiteman A, de Vogel EF (2000) Orchid genera of Thailand, Laos, Cambodia and Vietnam. NHN, Leiden, $118 \mathrm{pp}$

Singchi C, Zhanhuo T, Yibo L (1999) Native Orchids of China in Colour. Science Press, Beijing, New York, 416 pp

Smith JJ (1933) Enumeration of the Orchidaceae of Sumatra and neighbouring islands. Repert Spec Nov Regni Veg 32:129-386

Szlachetko DL, Mytnik-Ejsmont J, Kras M, Rutkowski P, Baranow P, Górniak M (2010) Contribution to the Orchid Flora of WestCentral Africa. Wydawnictwo Uniwersytetu Gdańskiego, 398 pp

Valmayor HL (1984) Orchidiana Philippiniana 2. Eugenio Lopez Foundation, Manila. Philippine, $760 \mathrm{pp}$

Wood JJ, Cribb PJ (1994) A check-list of the Orchids of Borneo. Royal Botanic Gardens, Kew, 409 pp

Wood JJ, Beaman RS, Beaman JH (1993) The plants of Mount Kinabalu 2. Orchids. Royal Botanic Gardens, Kew, 411 pp 